\title{
Identification of barley genotypes with higher protein content coupled with bold grains for food and malt barley improvement under sub-tropical climates
}

\author{
Dinesh Kumar*, RPS Vermaㄹ, Sneh Narwal, Jogendra Singh, Vishnu Kumar, Ajit Singh Kharub \\ and Gyanendra Pratap Singh \\ ICAR-Indian Institute of Wheat and Barley Research, Karnal -132 001, India \\ ${ }^{1}$ International Centre for Agricultural Research in the Dry Areas, Rabat, Morocco
}

\section{Article history}

Received: 16 August 2017

Revised : 01 November 2017

Accepted: 04 Deceber 2017

\section{Citation}

Kumar D, RPS Verma, S Narwal, J Singh, V Kumar, AS Kharub and GP Singh. 2017.Identification of barley genotypes with higher protein content coupled with bold grains for food and malt barley improvement under sub-tropical climates. Journal of Wheat Research 9(2): 94-100. doi.org/10.25174/22494065/2017/73253

\section{*Corresponding author}

Email: dkbiochem69@gmail.com

(C) Society for Advancement of Wheat and Barley Research

\begin{abstract}
Grain protein content is very important trait with respect to barley grains meant for food, feed and malt purposes. Barley grain protein content was evaluated in several genotypes for two years at different locations under sub-tropical climates in India. The grain protein content was affected both by the genotype (varied from 11.4-14.7 \% dwb during 2012-13 and 9.9-15.4\% dwb during 2013-14) and growing location (varied from 10.5-15.5 \% dwb during 2012-13 and 11.4-15.1\% during 2013-14). The genotypes with unique combination of moderately higher protein content coupled with plump grains were identified. These genotypes can be useful resources for malt barley improvement programme, meant for food purposes under sub-tropical climates having relatively shorter grain filling duration.
\end{abstract}

Keywords: Barley, protein, genotype, growing location, malting quality

\section{Introduction}

Barley (Hordeum vulgare L.) is a very ancient grain and is considered as a sacred grain in the Indian culture. However, the area and production of barley decreased in India and most parts of the world upto the year 2000, mainly because of availability of higher yielding dwarf wheat genotypes and development of irrigation facilities. But, the area of barley is more or less stabilized from past one decade in India, possibly because of increasing use of barley by the malt and food industry. Barley grain is one of the preferred grain for making malt due to its attached husk and relatively better enzymatic activity as compared to other grains. The malt made from barley is mainly used for brewing and some portion goes for making health foods. For brewing the protein content should be low (preferably between 9.0-11.0\%), but for food and feed barley and food malt, it has always been desirable to have higher protein quantity and quality (See et al., 2002). Literature reports say that there is an inverse relationship between protein and starch content of barley grain, that means selecting higher protein genotypes may lead to lesser extract recovery from the malt (Griffey et al., 2010). A negative correlation between grain protein content and malt extract and a positive correlation between grain protein content and diastatic power have been reported (Wang et al., 2003). The barley grain protein content is influenced by the genotype, growing conditions and cultural practices mainly nitrogen application (Zhang et al., 2001).

Most of the studies conducted on barley grain have been conducted in temperate climates, where the crop gets a longer vegetative and grain filling period, whereas in case of sub-tropical climates of India the total crop duration 
is 130-140 days with effective grain filling period of 3040 days which is comparatively shorter. The restricted grain filling period influences the grain composition and getting all the desired malt or food barley parameters in barley grown under sub-tropical climates of India is a big challenge. Breeding barley genotypes with relatively higher protein content along with better malting quality traits are required to the demand of food malt industry in specific and food barley segment in general. Efforts to improve grain protein content through traditional breeding have had limited results because of complex genetic and environmental effects (Simmonds, 1995). The present investigation was undertaken to identify genotypes with higher protein content with higher bold grain percentage; influence of growing locations on protein content; and evaluation of malt quality of selected high protein genotypes.

\section{Materials and methods}

The experiment was conducted during the Rabi season of 2012-13 and 2013-14. During the year 2012-13 a total of 27 genotypes including 3 checks (Shebec, DWRUB 52 and RD 2668) were grown at five locations spread over north western plain zone (Karnal, Hisar and Ludhiana), north eastern plain zone (Faizabad) and northern hill zone (Bajaura). During the crop season of 2013-14, twenty genotypes including three checks (DWRUB 52, BH 902 and K 551) were grown at four locations including three locations in north western plain zone (Karnal, Ludhiana and Durgapura) and one location in north eastern plain zone (Rewa). Each genotype was grown in two rows of 2.5 meter each and after harvest grain samples were analysed at ICAR-IIWBR, Karnal for different quality traits. The crude protein content was estimated using FOSS Infratech Grain Analyser taking around 250 gram grains, thousand grain weight was taken after counting the grains on Pfeuffer make seed counter, test weight was estimated using ICAR-IIWBR designed test weight instrument and bold grain percentage (grains $>2.5 \mathrm{~mm}$ size) was estimated using Pfeuffer make Sortimat instrument. Two genotypes (BK 306 and DWRUB 52) were analysed for amino acid composition from CFTRI, Mysore. Three genotypes (BK 303, BK 306 and BK 316) along with six checks grown at ICAR-IIWBR, Karnal during 2012-13, were micromalted in the Joe White Micro-Malting system using $\mathrm{EBC}$ procedures to determine malt quality.
2.1 Statistical analysis : To find out the effect of genotype and growing location, the data was analysed in Crop Stat 7.2 (IRRI, Phillipines).

\section{Results and discussion}

Barley grain protein content is an important quality determinant. It is closely associated with food, feed and malt quality. For food and feed higher protein content is desirable, whereas for malt barley lower or moderate protein content is expected. Grain protein content affects malting quality in many ways, including yeast nutrition, haze formation and enzyme activities (Cai et al., 2013). The effect of genotype and growing location was studied on grain protein content, grown under sub-tropical situations of India and results are discussed below:

3.1 Effect of genotype on protein content and other grain physical parameters: During the year 2012-2013, the effect of genotype was found significant on grain protein content, thousand grain weight, test weight and bold grain percentage (Table 1). The genotypes BCU 2241, BCU 5070, BCU 5173, BCU 5474, BK 306 and BK 316 had significantly higher protein content as compared to the best check RD 2668 and mean value of protein content was more than $14.0 \% \mathrm{dwb}$ in all these genotypes. Out of these six genotypes, four genotypes (BCU 2241, BCU 5070, BK 306 and BK 316) were unique in the sense that, these had higher bold grain percentage $>$ $85 \%$ ). Normally, higher protein content is associated with shrivelled grains due to inverse relationship between grain protein and starch content. One of the genotype, BK 316 had numerically highest bold grain percentage of 95.1\% among all the genotypes tested. Grain number and thousand-grain weight (TGW) are considered to be the most important grain yield components in case of cereal crops including barley. Thousand grain weight is considered as an important parameter in case of two-row barleys as higher thousand grain weight is important contributing factor in addition to the higher tillering capacity for yield compensation as compared to six rowed varieties. Furthermore, the TGW trait is widely used as a standard indicator for grain development and quality and presently is limiting factor for six row barley in India. Significant differences were observed for TGW in the genotypes tested during the year 2013. The genotypes BH 969, BHS 404, BK 306 and PL 867 had significantly higher TGW as compared to the best check DWRUB 52. 
The genotype BK 306 had the highest numerical value of TGW of $56.1 \mathrm{~g}$ and interestingly this genotype has highest numerical value of protein content $(14.7 \% \mathrm{dwb})$. In case of test weight, only one hull less genotype BHS 404 (73.0) had expectedly higher value than the best check DWRUB 52 (66.6). All the high protein genotypes had test weight value of $60.0 \mathrm{~kg} / \mathrm{hl}$ or more except BK $306(58.5 \mathrm{~kg} / \mathrm{hl})$.

During the year 2013-2014, the effect of genotype on grain protein content and other grain parameters was found statistically significant (Table 3). A total of 11 genotypes had significantly higher protein content than best check DWRUB 52 (11.4\%), whereas values for BK 306 (12.6\%) and DWR $49(12.6 \%)$ were statistically at par to DWRUB 52. Four genotypes (BCU 1224, BCU 2237, BCU 2241 and BCU 5173) had protein content values of $>14.0 \%$ (dwb). The genotypes BCU 2237, BCU 2241 and BCU 4966 had higher bold grain percentage $(>85.0 \%)$ coupled with higher protein content. The genotype BCU 2241 was tested for both the years and was confirmed for higher protein content alongwith bold grain percentage over the locations and years. TGW values were significantly higher in BCU 4966, BK 303, BK 306, DWR 96, DWR 97 and DWR 49 as compared to best check BH 902 (43.4). The genotypes BCU 4966 and DWR 97 had a good combination of good protein, higher TGW and bold grain percentage of $>92.0 \%$. No significantly superior genotype could be identified for better test weight as compared to best check DWRUB $52(66.9 \mathrm{~kg} / \mathrm{hl})$, however the genotype BCU 4966 also had test weight value of $67.7 \mathrm{~kg} / \mathrm{hl}$.

Based upon the two years study, few genotypes (BCU 2241, BCU 2237, BCU 5070 and BCU 1224 with mean protein content of $>14 \% \mathrm{dwb}$ and bold grain percentage of $>75 \%$ and one genotype BK 306 with mean protein content of $13.7 \%$ and bold grain percentage of $93.3 \%$ ) have been identified, which seems to be promising genotypes for protein content improvement. These genotypes can be suitable sources for food and food malt barley improvement programme in India. Barley grain protein content is under polygenic control, with many QTLs having been mapped on all seven chromosomes, mainly on $2 \mathrm{H}$, $4 \mathrm{H}, 5 \mathrm{H}$ and $6 \mathrm{H}$ (Cai et al., 2013 ). Genotypic variation in barley population has been studied by Jukanti and Fischer (2008) and they have stated that nitrogen retranslocation to developing cereal kernels, is influenced by the major
QTL on chromosome 6, explaining approximately $46 \%$ of the variability in grain protein concentration. They have further stated that in high-grain protein germplasm, earlier leaf senescence and leaf proteolysis leads to enhanced organic $\mathrm{N}$ availability, increased $\mathrm{N}$ retranslocation to the developing kernels and earlier/increased seed storage protein accumulation. Further studies at biochemical and genetic/molecular level are required in the identified genotypes, to understand the deposition of higher protein along with higher bold grain percentage.

3.2 Effect of location on protein content and other grain physical parameters: There was significant effect of growing location on all the four parameters analysed for both the years (Table 2 and Table 4). During the year 2012-13 lowest protein content $(10.5 \% \mathrm{dwb})$ was achieved in Bajaura, which being in hills has relatively longer crop growing duration and which may had resulted in lower values of protein content. Highest value of protein content was achieved at Hisar $(15.5 \% \mathrm{dwb})$ in north western plain zone. TGW was significantly higher at Bajaura (49.7 g) among the locations, probably because of longer crop duration and better grain filling thereof. The range of TGW varied from $42.2 \mathrm{~g}$ to $49.7 \mathrm{~g}$. The values among different locations in NWPZ were non-significant. Test weight was highest at Karnal $(66.3 \mathrm{~kg} / \mathrm{hl})$ and values ranged from 60.4 to $66.3 \mathrm{~kg} / \mathrm{hl}$. Bold grain percentage was significantly higher at Ludhiana, Faizabad and Bajaura as compared to Karnal and Hisar. During the year 20132014, lowest value for protein content was obtained at Rewa (11.4\% dwb) and highest at Ludhiana (15.1\% dwb). TGW values ranged from $42.4 \mathrm{~g}$ (Ludhiana) to $47.9 \mathrm{~g}$ (Durgapura), test weight values from $60.5 \mathrm{~kg} / \mathrm{hl}$ (Rewa) to $67.0 \mathrm{~kg} / \mathrm{hl}$ (Karnal) and bold grain percentage from 80.0 (Ludhiana) to 89.4 (Karnal). Mehari et al. (2015) have reported strong effect of growing environment on barley grain protein content. They suggested that in breeding programs best genotype is defined as one that has higher yield and stable across wider environments. In our study also, grain protein content is affected both by genotype as well as growing location. Therefore, there is a need to breed/develop genotypes with better stability of quality traits across the environments under sub-tropical climates. Molecular marker based selections can be one of the ways to achieve grain protein stability (Cai et al., 2013) which may complement the conventional methods. 
Table 1. Mean protein content, thousand grain weight (TGW), test weight and bold grain percentage in different genotypes during the year 2012-13

\begin{tabular}{lcccl}
\hline Genotype & $\begin{array}{c}\text { Protein } \\
(\% \mathrm{dwb})\end{array}$ & $\begin{array}{c}\text { TGW } \\
(\mathrm{g})\end{array}$ & $\begin{array}{c}\text { Test wt } \\
(\mathrm{kg} / \mathrm{hl})\end{array}$ & $\begin{array}{c}\text { Bold } \\
\text { grain }(\%)\end{array}$ \\
\hline BCU614 & 12.7 & 38.2 & 60.7 & 83.5 \\
BCU1224 & 13.0 & 40.5 & 61.5 & 80.5 \\
BCU2030 & 12.2 & 45.3 & 58.1 & 79.6 \\
BCU2237 & 13.6 & 43.0 & 65.1 & 89.1 \\
BCU2241 & 14.1 & 41.4 & 64.6 & 89.9 \\
BCU4963 & 12.6 & 46.5 & 66.0 & 92.7 \\
BCU4966 & 13.2 & 48.4 & 66.6 & 92.8 \\
BCU4968 & 13.7 & 43.4 & 62.7 & 80.4 \\
BCU4969 & 12.8 & 42.6 & 63.2 & 68.0 \\
BCU4980 & 13.6 & 35.6 & 60.1 & 83.1 \\
BCU4982 & 13.6 & 43.4 & 60.8 & 83.6 \\
BCU5070 & 14.4 & 42.6 & 63.2 & 85.9 \\
BCU5173 & 14.4 & 43.2 & 60.5 & 64.8 \\
BCU5474 & 14.0 & 40.7 & 60.5 & 58.8 \\
\hline
\end{tabular}

\begin{tabular}{lllcc}
\hline Genotype & $\begin{array}{l}\text { Protein } \\
(\% \text { dwb })\end{array}$ & $\begin{array}{l}\text { TGW } \\
(\mathrm{g})\end{array}$ & $\begin{array}{c}\text { Test wt } \\
(\mathrm{kg} / \mathrm{hl})\end{array}$ & $\begin{array}{c}\text { Bold } \\
\text { grain }(\%)\end{array}$ \\
\hline BH969 & 12.2 & 52.3 & 64.3 & 84.7 \\
BHS404 & 12.6 & 51.9 & 73.0 & 70.7 \\
BK306 & 14.7 & 56.1 & 58.5 & 90.2 \\
BK316 & 14.1 & 49.0 & 62.7 & 95.1 \\
DWR49 & 13.3 & 48.7 & 63.5 & 87.1 \\
DWRB106 & 12.1 & 44.7 & 64.4 & 88.1 \\
NBD1541 & 12.5 & 34.2 & 53.7 & 71.8 \\
PL867 & 12.1 & 52.8 & 65.4 & 92.9 \\
PL870 & 11.6 & 51.4 & 67.3 & 91.3 \\
RD2851 & 12.6 & 45.8 & 62.8 & 86.9 \\
SHEBEC (c) & 11.4 & 39.0 & 60.6 & 57.7 \\
DWRUB 52 (c) & 11.5 & 46.1 & 66.6 & 82.1 \\
RD 2668 (c) & 12.3 & 42.2 & 62.9 & 60.0 \\
LSD (5 \%) & 1.5 & 5.4 & 2.8 & 13.6 \\
\hline
\end{tabular}

Table 2. Mean protein content, thousand grain weight (TGW), test weight and bold grain percentage at different locations during the year 2012-13

\begin{tabular}{lcccc}
\hline Location & $\begin{array}{c}\text { Protein } \\
(\% \mathrm{dwb})\end{array}$ & $\begin{array}{c}\text { TGW } \\
(\mathrm{g})\end{array}$ & $\begin{array}{c}\text { Test wt } \\
(\mathrm{kg} / \mathrm{hl})\end{array}$ & $\begin{array}{c}\text { Bold } \\
\text { grain }(\%)\end{array}$ \\
\hline Karnal & 14.6 & 43.5 & 66.3 & 76.3 \\
Hisar & 15.5 & 43.5 & 63.2 & 70.7 \\
Ludhiana & 12.0 & 42.2 & 64.3 & 84.6 \\
\hline
\end{tabular}

\begin{tabular}{lcccc}
\hline Location & $\begin{array}{c}\text { Protein } \\
(\% \mathrm{dwb})\end{array}$ & $\begin{array}{c}\text { TGW } \\
(\mathrm{g})\end{array}$ & $\begin{array}{c}\text { Test wt } \\
(\mathrm{kg} / \mathrm{hl})\end{array}$ & $\begin{array}{c}\text { Bold } \\
\text { grain }(\%)\end{array}$ \\
\hline Faizabad & 12.4 & 45.0 & 60.4 & 86.1 \\
Bajaura & 10.5 & 49.7 & 60.5 & 88.6 \\
LSD $(5 \%)$ & 0.7 & 2.3 & 1.2 & 5.9 \\
\hline
\end{tabular}

Table 3. Mean protein content, thousand grain weight (TGW), test weight and bold grain percentage in different genotypes during the year 2013-14

\begin{tabular}{lcccl}
\hline Genotype & $\begin{array}{c}\text { Protein } \\
(\% \mathrm{dwb})\end{array}$ & $\begin{array}{c}\text { TGW } \\
(\mathrm{g})\end{array}$ & $\begin{array}{c}\text { Test wt } \\
(\mathrm{kg} / \mathrm{hl})\end{array}$ & $\begin{array}{c}\text { Bold } \\
\text { grain }(\%)\end{array}$ \\
\hline BCU 1224 & 15.1 & 40.1 & 60.5 & 75.8 \\
BCU 2237 & 14.8 & 47.1 & 64.6 & 86.1 \\
BCU 2241 & 15.0 & 47.8 & 66.8 & 89.3 \\
BCU 4966 & 13.4 & 53.5 & 67.7 & 93.8 \\
BCU 4968 & 13.9 & 42.9 & 64.2 & 84.4 \\
BCU 4980 & 12.8 & 35.0 & 63.1 & 81.1 \\
BCU 4982 & 13.7 & 38.8 & 61.1 & 74.7 \\
BCU 5070 & 13.9 & 39.0 & 62.0 & 73.6 \\
BCU 5173 & 15.4 & 41.1 & 61.1 & 59.5 \\
BK 303 & 12.7 & 52.0 & 64.8 & 96.1 \\
BK 306 & 12.6 & 54.3 & 64.6 & 96.3 \\
\hline
\end{tabular}

\begin{tabular}{lllcc}
\hline Genotype & $\begin{array}{l}\text { Protein } \\
(\% \mathrm{dwb})\end{array}$ & $\begin{array}{l}\text { TGW } \\
(\mathrm{g})\end{array}$ & $\begin{array}{c}\text { Test wt } \\
(\mathrm{kg} / \mathrm{hl})\end{array}$ & $\begin{array}{c}\text { Bold } \\
\text { grain }(\%)\end{array}$ \\
\hline BK 316 & 11.7 & 40.3 & 64.3 & 85.6 \\
DWR 96 & 12.4 & 51.0 & 63.9 & 94.8 \\
DWR 97 & 13.1 & 56.4 & 63.4 & 93.1 \\
DWR 49 & 12.6 & 51.1 & 66.8 & 87.9 \\
VJM 516 & 12.2 & 42.7 & 64.8 & 92.9 \\
VJM 522 & 12.2 & 40.9 & 64.2 & 90.1 \\
DWRUB 52 (c) & 11.4 & 42.9 & 66.9 & 80.5 \\
BH 902 (c) & 9.9 & 43.4 & 60.2 & 88.7 \\
K 551 (c) & 11.3 & 43.2 & 59.7 & 79.7 \\
LSD (5 \%) & 1.2 & 7.2 & 2.6 & 10.6 \\
& & & & \\
\hline
\end{tabular}

Table 4. Mean protein content, thousand grain weight (TGW), test weight and bold grain percentage at different locations during the year 2013-14

\begin{tabular}{|c|c|c|c|c|c|c|c|c|c|}
\hline & & & & & & & & & \\
\hline Location & $\begin{array}{l}\text { Protein } \\
(\% \mathrm{dwb})\end{array}$ & $\begin{array}{l}\text { TGW } \\
(\mathrm{g})\end{array}$ & $\begin{array}{l}\text { Test wt } \\
(\mathrm{kg} / \mathrm{hl})\end{array}$ & $\begin{array}{c}\text { Bold } \\
\text { grain }(\%)\end{array}$ & Location & $\begin{array}{l}\text { Protein } \\
(\% \mathrm{dwb})\end{array}$ & $\begin{array}{c}\text { TGW } \\
(\mathrm{g})\end{array}$ & $\begin{array}{l}\text { Test wt } \\
(\mathrm{kg} / \mathrm{hl})\end{array}$ & $\begin{array}{c}\text { Bold } \\
\text { grain }(\%)\end{array}$ \\
\hline Karnal & 12.6 & 47.5 & 67.0 & 89.4 & Durgaura & 12.9 & 47.9 & 65.8 & 86.6 \\
\hline Rrewa & 11.4 & 42.9 & 60.5 & 84.9 & $\operatorname{LSD}(5 \%)$ & 0.5 & 3.2 & 1.2 & 4.7 \\
\hline Ludhiana & 15.1 & 42.4 & 61.7 & 80.0 & & & & & \\
\hline
\end{tabular}


Table 5. Comparison on amino acid composition (g/100 g protein) between BK 306 and DWRUB 52 grown at Karnal during 2013-14

\begin{tabular}{ccc}
\hline Amino acid & BK 306 & DWRUB 52 \\
\hline Asx & 5.51 & 6.47 \\
Glx & 28 & 25.64 \\
Ser & 4.01 & 4.25 \\
Gly & 4.1 & 4.57 \\
His & 1.99 & 2.06 \\
Arg & 4.31 & 4.38 \\
Thr & 3.17 & 3.36 \\
Ala & 4.38 & 4.85 \\
Pro & 12.9 & 11.77 \\
Tyr & 0.43 & 0.5 \\
Val & 5.31 & 5.42 \\
Met & 1.86 & 1.89 \\
Cys & 3.78 & 4.45 \\
Ile & 3.5 & 3.52 \\
Leu & 7.79 & 8.17 \\
Phe & 5.61 & 5.23 \\
Lys & 3.36 & 3.49 \\
\hline
\end{tabular}

3.3 Comparison of amino acid composition between BK 306 and DWRUB 52: Cereals provide a significant proportion of human and animal diets. However, the grains of most cereals species have a number of nutritional shortcomings and the primary problem is the low levels of essential amino acids, such as lysine and threonine in barley (Hansen et al., 2007). Amino acid composition (mg/100 $\mathrm{g}$ protein) shown that maximum contribution is made by glutamic acid and glutamine followed by proline. The content of most of the amino acids is comparable among both the genotypes with minor differences. It is important to note that the value of lysine, the most limiting essential amino acid in cereals, was $3.36 \mathrm{~g} / 100 \mathrm{~g}$ protein in BK 306 was comparable to DWRUB 52 (3.49 g/100 g protein). Dingle and McEwan (1972) reported that proline and glutamic acid accounted for the major increases in amino acids with increasing protein content, and cystine also contributed to a significant extent. However, in the

Table 6. Malting quality of moderately high protein genotypes grown at Karnal during 2012-13

\begin{tabular}{|c|c|c|c|c|c|c|c|c|}
\hline \multicolumn{9}{|c|}{ A. Grain Characters\# } \\
\hline Genotype & TW & TCW & Bold & Thin & Husk & Germ & Protein & Starch \\
\hline BK303 & 67.0 & 53.7 & 95.8 & 0.5 & 10.5 & 98.1 & 12.9 & 61.7 \\
\hline BK306 & 67.4 & 53.3 & 96.4 & 0.5 & 12.4 & 85.7 & 13.1 & 61.9 \\
\hline BK316 & 69.2 & 41.2 & 86.4 & 1.6 & 9.2 & 96.5 & 11.6 & 63.9 \\
\hline SHEBEC (c) & 60.4 & 31.3 & 40.3 & 30.9 & 7.3 & 100.0 & 13.7 & 62.3 \\
\hline ALFA93 (c) & 65.8 & 34.8 & 68.8 & 5.9 & 10.3 & 98.2 & 10.9 & 64.1 \\
\hline BCU73 (c) & 68.6 & 56.5 & 94.7 & 0.4 & 11.9 & 99.0 & 8.8 & 64.4 \\
\hline DWRUB52 (c) & 69.1 & 46.5 & 84.9 & 0.9 & 11.9 & 98.1 & 9.7 & 65.5 \\
\hline DWR28 (c) & 62.9 & 56.4 & 98.0 & 0.2 & 12.7 & 95.8 & 10.9 & 61.9 \\
\hline $\mathrm{K} 551$ (c) & 62.2 & 46.1 & 78.4 & 2.1 & 12.4 & 85.7 & 9.6 & 62.6 \\
\hline
\end{tabular}

present study it was true for proline and glutamic acid, not for cystine.

3.4 Malt quality analysis of selected high protein genotypes: Three genotypes identified for moderately higher protein $(>11.0 \%$ ) were grown at Karnal and evaluated for malt quality parameters along with six checks (Table 6; A, B \& C). The highest protein content among three genotypes was in BK 306(13.1), followed by BK 303(12.9) and lowest in BK 316 (11.6). Test weight of BK 316 was comparable to best check DWRUB 52, whereas bold grain percentage of $>90 \%$ was obtained in case of BK 303 and BK 306. The malt prepared from the genotypes had shown highest friability of malt in $\mathrm{BK} 316$, which was comparable to the best control Alpha 93. Hot water extract is the major criteria for any malt industry and values above $80 \%$ are desirable, the value of $82.66 \%$ was obtained in BK 316, which however was lower than two controls (Alpha 93 (85.7) and BCU 73 (84.2). The extract value of $>80 \%$ alongwith reasonably higher protein value can be useful combination for malt food purpose uses. The wort filtration rate was $>250 \mathrm{ml} / \mathrm{hr}$ in all the three genotypes tested, whereas desirable Kolbach index value of 42 was obtained in BK 316 among the three genotypes tested. On the basis of weighed score (as per the Analytical guidelines for barley breeders in India, finalized in first meeting of the "National Core Group on Malt Barley Development" at DWR, Karnal on 12 Dec., 1995 and revised during the annual workshop at IARI, New Delhi in August 2004 and further on 05 March, 2016 at ICAR-IIWBR, Karnal) of several parameters (Protein content was not included) the genotypes BK 316 (21/24) was at par or close to the best control BCU 73 despite having higher grain protein content than BCU 73. Genotypes with higher protein content $(>11 \% \mathrm{dwb})$ with good bold grain percentage could be useful sources for barley improvement for food malt segment. 
B. Malt parameters\#

\begin{tabular}{lcccccccc}
\hline Genotype & MY & FB & Hom & HWE & FR & pH & DP & KI \\
\hline BK303 & 87 & 53.6 & 85 & 75.0 & 265 & 6.2 & 118 & 39 \\
BK306 & 87 & 51.7 & 83 & 77.3 & 305 & 6.5 & 110 & 36 \\
BK316 & 78 & 78.3 & 98 & 82.6 & 320 & 5.9 & 111 & 42 \\
SHEBEC (c) & 81 & 71.2 & 96 & 77.8 & 300 & 6.5 & 108 & 38 \\
ALFA93 (c) & 82 & 74.5 & 98 & 85.7 & 290 & 6.5 & 118 & 42 \\
BCU73 (c) & 83 & 71.3 & 98 & 84.2 & 285 & 6.2 & 105 & 42 \\
DWRUB52 (c) & 84 & 60.3 & 95 & 80.8 & 280 & 6.6 & 111 & 38 \\
DWR28 (c) & 89 & 40.7 & 59 & 79.3 & 290 & 6.6 & 108 & 38 \\
K551 (c) & 87 & 52.6 & 86 & 79.3 & 225 & 6.3 & 114 & 36 \\
\hline
\end{tabular}

C. Weighed score genotypes\#

\begin{tabular}{lccccccccc}
\hline Genotype & TW & Bold & Husk & FB & HWE & FR & DP & KI & $\begin{array}{c}\text { Total } \\
(24)\end{array}$ \\
\hline BK303 & 3 & 3 & 3 & 1 & 0 & 3 & 2 & 2 & 17 \\
BK306 & 3 & 3 & 1 & 1 & 1 & 3 & 3 & 2 & 17 \\
BK316 & 3 & 1 & 3 & 3 & 3 & 3 & 2 & 3 & 21 \\
SHEBEC (c) & 0 & 0 & 3 & 3 & 1 & 3 & 3 & 2 & 15 \\
ALFA93 (c) & 3 & 0 & 3 & 3 & 3 & 3 & 2 & 3 & 20 \\
BCU73 (c) & 3 & 3 & 1 & 3 & 3 & 3 & 3 & 3 & 22 \\
DWRUB52 (c) & 3 & 2 & 1 & 2 & 3 & 3 & 2 & 2 & 18 \\
DWR28 (c) & 1 & 3 & 0 & 0 & 2 & 3 & 3 & 2 & 14 \\
K551 (c) & 1 & 2 & 1 & 1 & 3 & 2 & 2 & 2 & 14 \\
\hline
\end{tabular}

\# TW $=$ Test Weight $(<60=0,60-63=1,>63-65=2,>65=3)$, Bol= Bold grain $(\%)(($ Two-Row $)>92=3,88-92=2,80-87=1,<80=0 ; \quad($ Six-row $)=>82=3,78$ $82=2,70-77=1,<70=0)$, Hus $=\operatorname{Husk}(\%)(<10.5=3,10.6-11.5=2,11.6-12.5=1,>12.5=0)$, Pro= Protein, Fri $=$ Friability $(>65=3,55-65=2,45-55=1,<45=0)$, $\mathrm{HWE}=$ Hot water extract $(\%)($ Two-row $=>80.0=3,78-80=2,76-78=1,<76=0$; Six-row $=>78=3,76-78=2,74-76=1,<74=0), \mathrm{FR}=\mathrm{Filtration}$ rate $(>250=3$, $200-250=2,150-200=1,<150=0), \mathrm{DP}=$ Diastatic power $(<90=1,90-110=3,111-120=2,121-130=1,>130=0)$, BG= Beta glucan, KI= Kolbach index $(40-44 \%$ $=3,35-39 \& 45-49=2,30-34 \& 50-54=1,<30 \&>54=0)$

This study concludes that grain protein content is significantly affected by the genotype and growing locations in the sub-tropical climates of India. The genotype BCU 2241 has been identified having higher grain protein content coupled with higher bold grain percentage, which is normally a rare combination. The amino acids glutamine and glutamic acid followed by proline are the major contributor to the grain protein composition. Preliminary studies on few genotypes have shown that there is possibility of getting get good hot water extract from genotypes with $>11.0 \%$ protein content. The material identified in this study can be useful resources for food and malt (for food) barley improvement programme in the country as well as for basic studies related to grain protein accumulation under sub-tropical climates of India.

\section{Acknowledgement}

The authors are grateful to co-operators at different centres for supplying grain samples and to Mr. Yogesh Kumar for the technical assistance. 


\section{References}

1. Cai S, G Yu, X Chen, Y Huang, X Jiang, G Zhang and $X$ Jin. 2013. Grain protein content variation and its association analysis in barley. BMC Plant Biology 13: 35-45.

2. Dingle JG and JM McEwan. 1972. The amino acid content of some barley varieties grown in New Zealand. New Zealand Journal of Agricultural Research 15:516-526.

3. Jukanti AK and AM Fischer. 2008. A high-grain protein content locus on barley (Hordeum vulgare) chromosome 6 is associated with increased flag leaf proteolysis and nitrogen remobilization. Physiologia Plantarum 132: 426-439.

4. Michael Hansen M, M Lange, C Friis, G Dionisio, PB Holm and E Vincze. 2007. Antisense-mediated suppression of C-hordein biosynthesis in the barley grain results in correlated changes in the transcriptome, protein profile, and amino acid composition. Journal of Experimental Botany 58: 39873995.

5. Mehari M, S Alamerew and B Lakew. 2015. Genotype by environment interaction for protein content of malt barley genotypes using the additive main effect and multiplicative interaction effect model (AMMI) and genotype plus genotype by environment interaction (GGE) biplot. Asian Journal of Agricultural Research 9: 305-314.
6. See D, V Kanazin, K Kephart and T Blake. 2002. Mapping genes controlling variation in barley grain protein concentration. Crop Science 42: 680-685.

7. Simmonds NW. 1995. The relation between yield and protein in cereal grain. Journal of the Science of Food and Agriculture 67: 309-315.

8. Griffey C, W Brooks, M Kurantz, W Thomason, F Taylor, D Obert, R Moreau, R Flores, M Sohn and K Hicks. 2010. Grain composition of Virginia winter barley and implications for use in feed, food, and biofuels production. Journal of Cereal Science 51: 41-49.

9. Zhang G, J Chen, J Wang and S Ding. 2001. Cultivar and Environmental Effects on (1-3,1-4)- Beta-DGlucan and Protein Content in Malting Barley.Journal of Cereal Science 34: 295-301

10. Wang JM, GP Zhang, JX Chen, SR Ding and TY Zhou. 2003. Variation of grain and malt qualities in barley as affected by cultivars and environments. Agricultural Sciences in China 2:699-705. 